\title{
Assessment of Mutation in Marigold (Tagetes erecta L.) using Morphological and Molecular Markers
}

\author{
Jayoti Majumder $^{1^{*}}$, S. K. Singh ${ }^{1}$ and Manjusha Verma ${ }^{2}$ \\ ${ }^{1}$ ICAR-Indian Agricultural Research Institute, New Delhi-110012, India \\ ${ }^{2}$ ICAR-National Bureau of Plant Genetic Resource, New Delhi-110012, India \\ *Corresponding author
}

\begin{tabular}{|l|}
\hline Keyw or d s \\
Mutation in \\
Marigold, \\
Tagetes erect
\end{tabular}

\section{A B S T R A C T}

Variability caused by induced mutations is not essentially different from variability caused by spontaneous mutation during evolution. Although marigold (Tagetes spp.) is an important commercial crop the major breeding obstacle is non-availability of known sources for creating a novelty. Therefore, in vivo grown seedlings and in vitro raised proliferated cultures of marigold cultivar Pusa Narangi Gainda were subjected to gammairradiation to develop mutant populations. 11 Mutants were grown in the $\mathbf{M}_{1}$ generation and variants screened based on yield and morphological characters. The number of flowers per plant was recorded the maximum in both the parents i.e. Parent (53.24) followed by in vivo raised mutant $\mathrm{v} 4$ (40.78). The $\mathrm{v}_{4}$ exhibited maximum average flower diameter (5.71 $\mathrm{cm})$ with equivalence to Parent $(5.71 \mathrm{~cm})$. The maximum petal width among the mutants of $\mathrm{M}_{1}$ was observed in vitro raised mutant $\mathrm{v}_{8}(12.55 \mathrm{~mm})$. After screening the mutants through the morphology, genomic DNA from leaf samples was evaluated by six identified putative mutants (pm1-6) in PCR amplification using RAPD primers and the amplified DNA fragments from mutants were compared with their respective controls. Single marker and stepwise regression analysis were carried out in relation to percent variability indicate that the alleles OPA 10, markers are strongly associated with mutant identification. On the basis of dendogram generated, Putative mutant 3 shows highest dissimilarity than the parent $(0.24)$. The Putative mutants 5 and 6 were found to be similar with each other $(0.47)$ but were distinct from parent $(0.44)$

\section{Introduction}

Marigold (Tagetes erecta L.) is grown world over and are highly valued for their spectacular flowers, brilliant colours and delightful appearance and is endowed with large spectrum of commercial potentialities in medicinal and industrial sector. Presently, most of the varieties being grown in marigold are open-pollinated, which are less vigorous, uneven in height with low yield and are vulnerable to cross-pollination (Raghava, 1995). Therefore, the direct use of mutation is very valuable supplementary approach to plant breeding, particularly when it is desired to improve one or two easily identifiable 
characters in a well adopted variety. Mutation usually slightly alter the genetic base while the improved character(s) is (are) added, and the time required to breed the improved variety can be much shorter than when hybridization (Omar, 2008). Mutation breeding can play an important role in the improvement of a crop either directly or by supplementing the conventional breeding procedures where linkage between genes controlling desirable and undesirable characters can be broken with the help of radiation. Selection of appropriate mutagen and isolation of the mutants are difficult, but is important in mutation assisted breeding.

Marigold is basically seed propagated crop. The induced mutation either in vivo or in vitro can create mutant in $\mathrm{M}_{0}$ generation but most mutations may be recessive at this stage and plants may be chimeric so it is important to follow further generations for phenotypic screening purposes (Maple and Moller, 2007). Screening for mutants is usually carried out in the M1 or later generations when the population has got stabilized. This is because in the $M_{1}$ generation, the mutants will be heterozygous and as a result mutant which are dominant with respect to the wild would be expressed (Leyser, 2000). With the advent of in vitro and in vivo techniques, the interest in the combination of mutagenic treatment is possible now for many seed propagated as well as vegetatively propagated crops. Phenotypic selections based on traits that are conditioned by additive allelic effects can produce dramatic, economically important changes in breeding populations. Besides that, Molecular markers like RAPD provide a quick and reliable method for estimating genetic diversity and are the reliable tools to confirm mutant at early stages. In order to contribute towards improvement in marigold the present investigation was carried out keeping the above facts in mind, i.e., isolated putative mutants of Pusa Narangi Gainda derived through in vivo and in vitro induced mutagenesis were multiplied, and then to isolate the solid mutant through morphological and molecular characterization. The putative mutants will be multiplied in the successive generation.

\section{Materials and Methods}

Seedlings and in vitro grown proliferated cultures of var. Pusa Narangi Gainda were subjected to gamma irradiation $(5,10,15,20$, 25, 30, 35 and 40 Gy) at Nuclear Research Laboratory, IARI, New Delhi for in vivo and in vitro mutation. The mutated seedlings as well as the proliferated cultures along with the controls were grown. In $\mathrm{M}_{1}$, selfed seeds of variants derived by in vivo mutation $\left(v_{1}, v_{2}, v_{3}\right.$ and $\left.v_{4}\right)$ and in vitro mutation $\left(v_{5}, v_{6}, v_{7}, v_{8}, v_{9}\right.$, $v_{10}$ and $v_{11}$ ) with their respective controls were raised in nursery and finally transplanted in main field at $30 \times 30 \mathrm{~cm}$ distance. The quantitative parameter of the variants were analysed statistically in Completely Randomized Design the significance of treatment effects on various parameters was determined using analysis of variance (ANOVA).

The selected variants of M1 generation were again screened with RAPD primers.

For genomic DNA isolation, DNA was extracted using $500 \mathrm{mg}$ young leaves from the non-irradiated control (stock plant) and putative mutants with CTAB method described by Tsaftaris et al., (2006). The DNA concentration of each sample was confirmed by using VersaFluor ${ }^{\mathrm{TM}}$ Flurometer (BIORAD, USA). The isolated DNA was diluted in TE buffer having concentration upto 10ng/l and kept under the $-20^{\circ} \mathrm{C}$ until analysis. Amplification was performed as per the protocol described by William et al., (1990) with a few modifications. Five decamer RAPD primers (Operon Technology Inc., 
USA) were used for PCR amplification. The reaction volume was of $25 \mu \mathrm{l}$ of reaction containing $2.5 \mu \mathrm{l}$ of reaction buffer with $2.5 \mu \mathrm{l}$ $\mathrm{MgCl}_{2}, 0.5 \mu \mathrm{l}$ dNTPs, 1 unit of Taq DNA polymerase and $1.0 \mu \mathrm{l}$ primer. The total volume of the reaction mixture was adjusted using sterile deionized water. The amplification was performed in Biometra ${ }^{\circledR}$ PCR thermocycler. Thermal cycles were programmed for initial denaturation at $94^{\circ} \mathrm{C}$ for $4 \mathrm{~min}$. In each cycle denaturation was for one min at $94^{0} \mathrm{C}$, annealing for $1 \mathrm{~min}$ at $32^{\circ} \mathrm{C}$ and extension for $2 \mathrm{~min}$ at $72^{\circ} \mathrm{C}$ was performed with the final extension after 35 cycles for $10 \mathrm{~min}$. Amplification was repeated thrice for each primer. The PCR product was separated on $1.4 \%$ agarose gel and visualized with ethidium bromide staining. Gels were photographed using AlphaEase ${ }^{\mathrm{TM}}$ software.

Bands of RAPD gels were scored as either present (1) or absent (0) for the genotypes studied. Common band analysis was conducted using the computer programme NTSYS-PC Ver. 1.8. (Rohlf, 2000) to determine the genetic distances values between the genotypes. The gel images depicting the genetic distances were then used as input data for cluster analysis to generate dendograms.

\section{Results and Discussion}

The morphological characteristics of the variants are presented in the Table 1. Among them, the maximum days were taken to germinate the seed in $v_{3}$ (5.8 days), followed by Parent and $v 1$ (5.67 days) while, the minimum days required for germination was in $v_{11}$ (5.23 days). It was evident from the Table 1, that there was non-significant effect on the average days to bud initiation among the mutants and their parents. The maximum number of days required for anthesis was noted in the $v_{1}$ (71.89 days) and then the $v_{7}$ (71.45). The number of flowers per plant was recorded the maximum in both the parents i.e.
Parent (53.24) followed by $v 4$ (40.78). The number of flowers per plant was significantly reduced compared to their respective parent (control). Among the mutants derived in $\mathrm{M}_{1}$, $v_{4}$ exhibited maximum average flower diameter $(5.71 \mathrm{~cm})$ with equivalence to Parent $(5.71 \mathrm{~cm})$ while, minimum in $v_{6}(5.33 \mathrm{~cm})$. Among the parents, the minimum flower diameter was exhibited by $v_{1}(5.37 \mathrm{~cm})$. Although the obtained results of flower diameter was statistically non-significant at $5 \%$ LSD. The maximum petal width among the mutants of $\mathrm{M}_{1}$ was observed in $v_{8}(12.55$ $\mathrm{mm})$ being statistically at par with $v_{3}(12.47$ $\mathrm{mm})$. The parents of both type of mutant showed non-significant variation in petal width. The highest harvest index was found Parent $(48.33 \%)$ while, lowest harvest index was recorded in $v_{11}(31.34 \%)$. Among the mutants the highest harvest index was obtained in $v_{4}(45.45 \%)$ which is at par with $v_{2}(45.34 \%)$. Out of all, highest seed wt. was recorded in $v_{10}(241.35 \mathrm{mg})$ followed by $v_{1}$ (241.24 mg). Among different parent of the mutants, the maximum seed wt. was noticed in Parent $(240.93 \mathrm{mg})$. The isolated six putative mutants (pm1, pm2, pm3, pm4, pm5, pm6) were obtained in $\mathrm{M}_{1}$ and were subjected for molecular characterization in Table 2.

One of the mutagens which have been successfully used to cause beneficial induced mutation in crops is gamma ray (Omar, 2008). There are chances to obtain somatic epitypic changes as well as genetic changes. In case of gamma irradiation the chances of epitypic change reduces (Sangyoung et al., 2007). But, marigold is a cross pollinated crop and highly heterozygous (Raghava, 1995). In the cases like seed germination, may be attributed to the occurrence of seeds with completely developed embryos which could not be affected by the gamma irradiation (Omar et $a l .$, 2008). Three mutants have been isolated naming Putative mutants 2, 5 and 6 exhibited a larger bloom. 
Table.1 Morphological analysis of variants grown in M1

\begin{tabular}{|c|c|c|c|c|c|c|c|c|c|}
\hline $\begin{array}{l}\text { Sl. } \\
\text { No. }\end{array}$ & Genotype & $\begin{array}{l}\text { Days to seed } \\
\text { germination }\end{array}$ & $\begin{array}{l}\text { Days to } \\
\text { anthesis }\end{array}$ & $\begin{array}{l}\text { No. of } \\
\text { flowers } \\
\text { per plant }\end{array}$ & $\begin{array}{l}\text { Flower } \\
\text { diameter } \\
(\mathrm{cm})\end{array}$ & $\begin{array}{l}\text { Flower } \\
\text { colour }\end{array}$ & $\begin{array}{l}\text { Width of } \\
\text { petal } \\
\text { (mm) }\end{array}$ & $\begin{array}{c}\text { Harvest } \\
\text { index } \\
(\%)\end{array}$ & $\begin{array}{c}100 \\
\text { seed } \\
\text { wt.(mg) }\end{array}$ \\
\hline 1. & Parent & 5.67 & 70.80 & 53.24 & 5.71 & orange & 11.24 & $\begin{array}{c}48.33 \\
(43.86)\end{array}$ & 240.93 \\
\hline 2. & $v_{1}$ & 5.67 & 71.89 & 30.65 & 5.37 & orange & 12.04 & $\begin{array}{c}44.33 \\
(41.55)\end{array}$ & 241.24 \\
\hline 3. & $v_{2}$ & 5.54 & 67.89 & 21.34 & 5.59 & orange & 12.25 & $\begin{array}{c}45.34 \\
(42.30)\end{array}$ & 239.45 \\
\hline 4. & $v_{3}$ & 5.65 & 70.23 & 25.67 & 5.45 & orange & 12.47 & $\begin{array}{c}38.67 \\
(38.35)\end{array}$ & 238.78 \\
\hline 5. & $v_{4}$ & 5.45 & 70.45 & 40.78 & 5.71 & orange & 12.33 & $\begin{array}{c}45.45 \\
(42.30)\end{array}$ & 240.13 \\
\hline 6. & $v_{5}$ & 5.52 & 70.16 & 30.56 & 5.67 & orange & 11.45 & $\begin{array}{c}35.78 \\
(36.69)\end{array}$ & 235.67 \\
\hline 7. & $v_{6}$ & 5.55 & 69.9 & 26.67 & 5.33 & orange & 11.19 & $\begin{array}{c}32.56 \\
(34.76)\end{array}$ & 236.45 \\
\hline 8. & $v_{7}$ & 5.80 & 71.45 & 31.78 & 5.34 & orange & 12.45 & $\begin{array}{c}34.87 \\
(35.85)\end{array}$ & 239.56 \\
\hline 9. & $v_{8}$ & 5.65 & 70.12 & 27.45 & 5.50 & orange & 12.55 & $\begin{array}{c}32.12 \\
(34.51)\end{array}$ & 240.56 \\
\hline 10. & $v_{9}$ & 5.38 & 71.45 & 29.04 & 5.65 & orange & 12.45 & $\begin{array}{c}34.12 \\
(35.73)\end{array}$ & 238.94 \\
\hline 11. & $v_{10}$ & 5.45 & 69.23 & 24.56 & 5.35 & orange & 12.45 & $\begin{array}{c}31.45 \\
(34.08)\end{array}$ & 241.35 \\
\hline 12. & $v_{11}$ & 5.23 & 70.11 & 25.67 & 5.47 & orange & 12.34 & $\begin{array}{c}31.34 \\
(34.02)\end{array}$ & 238.78 \\
\hline & $S E$ & 0.34 & 0.69 & 1.02 & 1.33 & & 0.31 & 0.67 & 1.23 \\
\hline & CD at $5 \%$ & 1.19 & 9.92 & 7.85 & 0.27 & - & 0.48 & 1.85 & 11.23 \\
\hline
\end{tabular}

Table.2 The mutants used for molecular analysis

\begin{tabular}{|l|l|l|l|}
\hline Sl. No & Name & $\begin{array}{l}\text { Derived from } \\
\text { (Plant no.) }\end{array}$ & Distinguishing feature \\
\hline 1. & Putative mutant $1(\mathrm{pm} 1)$ & 3 & Flower light orange (orange 10 YR) \\
\hline $\mathbf{2 .}$ & Putative mutant $2(\mathrm{pm} 2)$ & 21 & Flower of larger diameter $8.5 \mathrm{~cm})$ \\
\hline $\mathbf{3 .}$ & Putative mutant $3(\mathrm{pm} 3)$ & 23 & Early flowering (in 47.89 days) \\
\hline $\mathbf{4 .}$ & Putative mutant $4(\mathrm{pm} 4)$ & 14 & Flower light orange $($ orange $10 \mathrm{YR})$ \\
\hline $\mathbf{5 .}$ & Putative mutant $5(\mathrm{pm} 5)$ & 3 & Flower of larger diameter $(7.5 \mathrm{~cm})$ \\
\hline $\mathbf{6 .}$ & Putative mutant $6(\mathrm{pm} 6)$ & 25 & wider petals width $(14 \mathrm{~mm})$ \\
\hline
\end{tabular}


Table.3 Characteristics of RAPD primers generated by selected primers

\begin{tabular}{|c|c|c|c|c|c|c|c|c|c|c|c|}
\hline $\begin{array}{l}\text { Sl } \\
\text { No. }\end{array}$ & Primers & $\begin{array}{l}\text { Sequence } \\
\left(5^{\prime}-3^{\prime}\right)\end{array}$ & $\begin{array}{l}\text { Total No. } \\
\text { of ampl- } \\
\text { ification } \\
\text { product }\end{array}$ & $\begin{array}{l}\text { No. of } \\
\text { polymorphic } \\
\text { amplification } \\
\text { product }\end{array}$ & $\begin{array}{c}\% \\
\text { polymer- } \\
\text { phism }\end{array}$ & $\begin{array}{l}\text { Average } \\
\text { amplificat- } \\
\text { product/cv./ } \\
\text { primer }\end{array}$ & $\begin{array}{l}\text { Molecular } \\
\text { weight } \\
\text { range } \\
\text { (bp) }\end{array}$ & $\begin{array}{c}\text { Effective } \\
\text { Multiplex } \\
\text { Ratio } \\
\text { (EMR) }\end{array}$ & $\begin{array}{l}\text { Diversity } \\
\text { Index } \\
\text { (DI) }\end{array}$ & $\begin{array}{l}\text { Marker } \\
\text { Index } \\
(\mathrm{MI})\end{array}$ & $\begin{array}{l}\text { Primer } \\
\text { Resolving } \\
\text { Power } \\
\text { (Rp) }\end{array}$ \\
\hline 1 & OPA 3 & AGTCAGCCAC & 5 & 2 & 40.0 & 1.20 & $550-900$ & 0.8 & 0.12 & 0.096 & 3.2 \\
\hline 2 & OPA 10 & GTGATCGCAG & 8 & 5 & 62.5 & 1.87 & $300-1200$ & 3.15 & 0.18 & 0.56 & 2.65 \\
\hline 3 & OPB 10 & GGGGGTCTTT & 4 & 1 & 25.0 & 3.50 & $500-1500$ & 0.25 & 0.08 & 0.02 & 1.2 \\
\hline 4 & OPD 2 & GTGCCCGTCA & 5 & 3 & 60.0 & 2.64 & $375-1300$ & 1.5 & 0.12 & 0.18 & 1.42 \\
\hline 5 & OPD 7 & GTCCCGACGS & 3 & 1 & 33.3 & 3.00 & 500-1000 & 1.0 & 0.03 & $\mathbf{0 . 0 3}$ & 2.68 \\
\hline
\end{tabular}

Table.4 Jaccard's similarity coefficient values for RAPD markers

\begin{tabular}{|l|l|l|l|l|l|l|l|}
\hline & parent1(in vivo) & parent 2(in vitro) & $\mathrm{m} 1$ & $\mathrm{~m} 2$ & $\mathrm{~m} 3$ & $\mathrm{~m} 4$ & $\mathrm{~m}$ \\
\hline parent 1(in vivo) & & & & & & \\
\hline parent2(in vitro) & 1 & & & & & \\
\hline $\mathrm{m} 1$ & 0.70 & 0.70 & & & & \\
\hline $\mathrm{m} 2$ & 0.58 & 0.58 & 0.75 & & & \\
\hline $\mathrm{m} 3$ & 0.24 & 0.24 & 0.40 & 0.36 & & \\
\hline $\mathrm{m} 4$ & 0.61 & 0.61 & 0.78 & 0.61 & 0.22 & & \\
\hline $\mathrm{m} 5$ & 0.45 & 0.45 & 0.33 & 0.4 & 0.54 & 0.37 & \\
\hline $\mathrm{m} 6$ & $\mathbf{0 . 4 5}$ & $\mathbf{0 . 4 5}$ & $\mathbf{0 . 5 0}$ & $\mathbf{0 . 3 6}$ & $\mathbf{0 . 3 3}$ & $\mathbf{0 . 2 9}$ & $\mathbf{0 . 4 7}$ \\
\hline
\end{tabular}




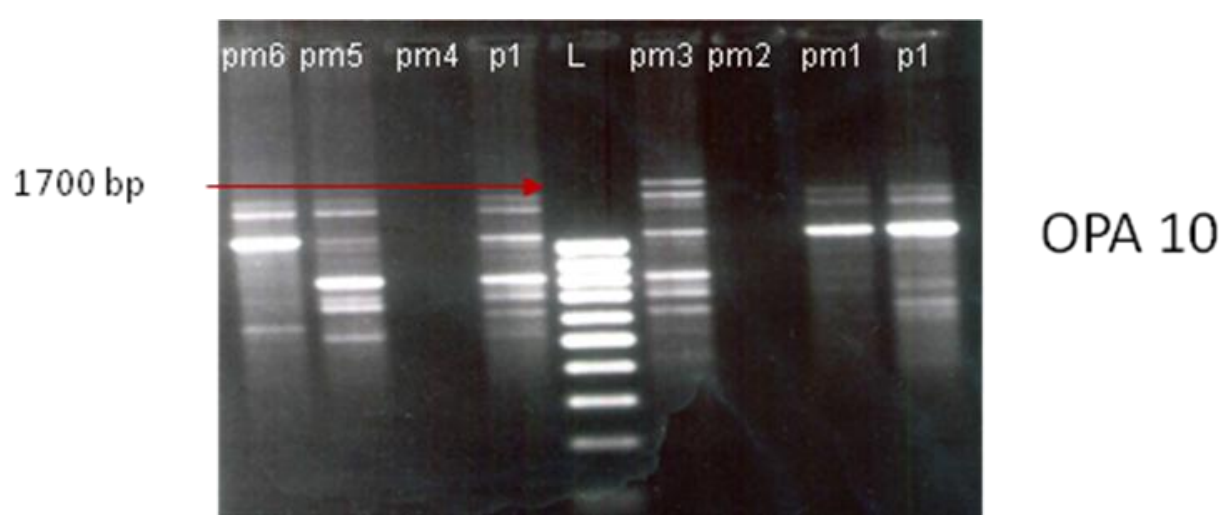

Fig.1 Amplification profiles of parents and mutants (8) RAPD Primer OPA 10, DNA source in the lanes are $\mathrm{p} 1=$ in vivo raised parent, $\mathrm{p} 2=$ in vitro raised parent, $\mathrm{pm} 1-\mathrm{pm} 3=$ in vivo raised mutants, pm4-pm6= in vitro raised mutants.

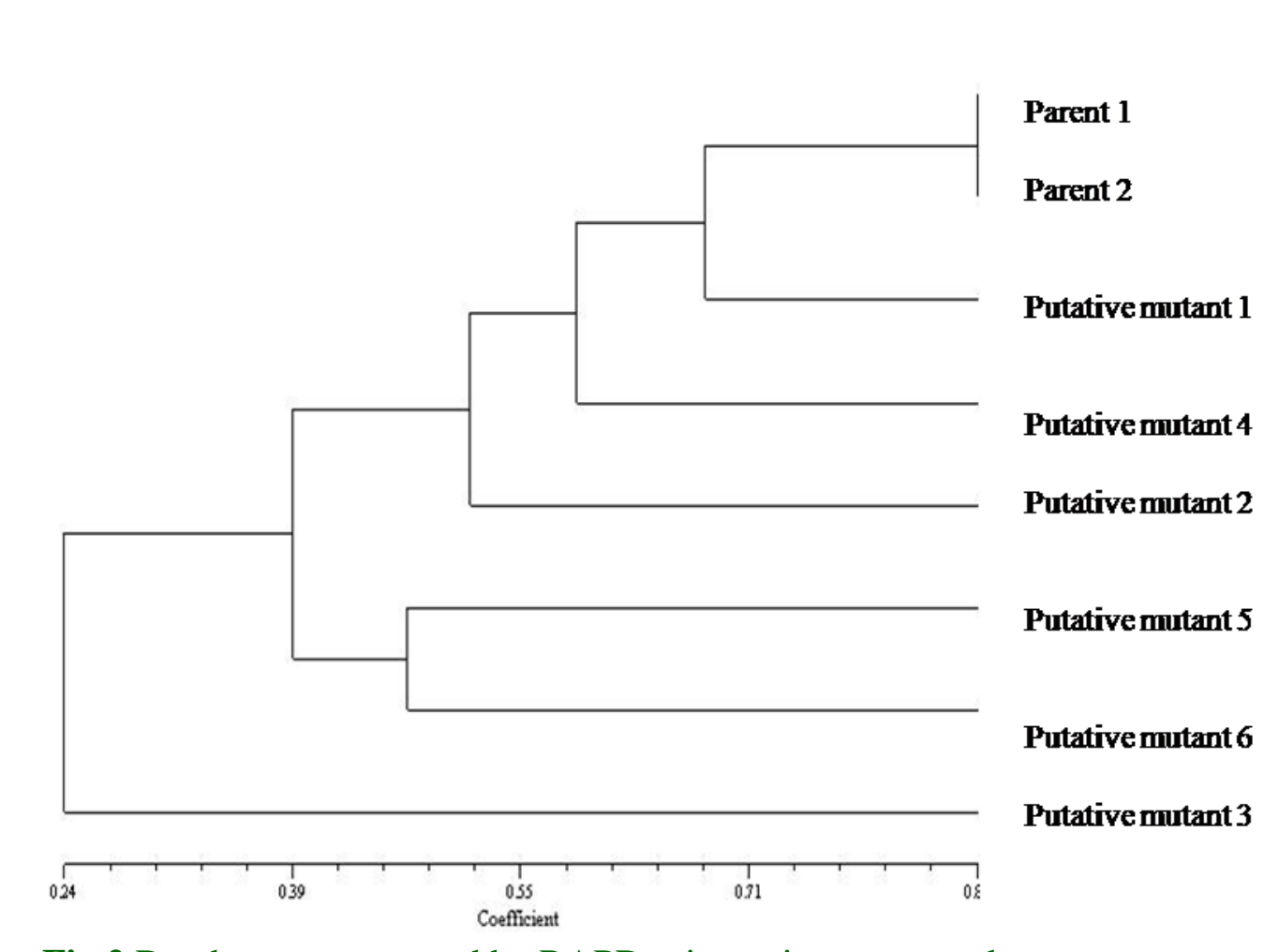

Fig.2 Dendogram generated by RAPD primers in mutant and parent genotype 


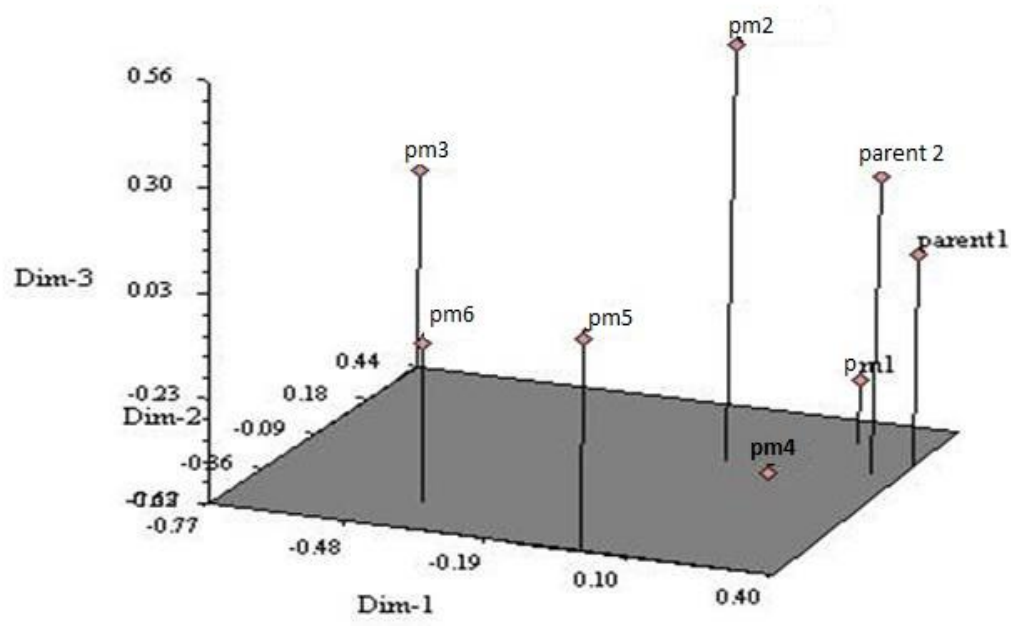

Fig.3 PCA analysis of RAPD primers for mutant and parent genotypes

It can be described as the change which occur in the $M_{1}$ generation, in information status and may be heritable, which is referred as epigenetic. The effective information content has not been changed only by means of the actions of a protein or proteins on DNA (Wang, 1993). However, marigold is a heterozygous crop, so there may be presence of widely diverse genes, the primary DNA sequence could be altered through irradiation but could not transferred in all the mutant population the similar type results were obtained by Lefort et al., (1999). Mutation can result in several different types of change in DNA sequences; these can have no effect, alter the product of a gene, or prevent the gene from functioning (Johnson et al., 1955). May be these are the reasons of deriving colour mutant $(v 4, v 2, v 5, v 6$ and $v 7)$ in $\mathbf{M}_{1}$. However, to the damaging effects that mutations can have on cells, organisms have evolved mechanisms such as DNA repair to remove mutations (Reiter et al., 1992). That would be the primary reason of not getting a true colour putative mutant, the conclusion lend the support from the finding of Bandyopadhyay et al., (1997).

\section{Molecular characterization of putative mutants}

The polymorphism survey among parents and the putative mutants was carried out using the bulked DNA sample in each case. A total of 60 RAPD primers were used for initial screening. Out of these 5 and 12 primers were selected based on clear and reproducible bands (Table 3). With 5 RAPD primers a total of 25 reproducible bands were obtained. Of these $12(48.0 \%)$ were polymorphic. The mean polymorphism level (i.e. per cent polymorphism) was $43.75 \%$ ranging from $25.0 \%$ (OPB 10) to $62.5 \%$ (OPA 10). The maximum number of polymorphic bands (5.0) was obtained with the primer OPA 10 followed by OPD 2 (3.0) and OPA 3 (2.0). The average number of polymorphic bands per primer was 2.4. Primer resolving power and effective multiplex ratio were found to be highest (3.15 and 2.65 respectively) for the primer OPA 10, while lowest was for the primer OPB 10 (0.02 and 1.2 respectively) (Table 3). Maximum marker index (MI) was observed 0.18 for the primer OPD 7 and also diversity index (DI) was comparatively higher (0.12). 
Genetic diversity between parents and obtained putative mutants accessions were determined on the basis of Jaccard's Pairwise Similarity Coefficients (Table 4). In RAPD analysis, the greatest similarity $(0.78)$ has been seen in between Putative mutant 1 and Putative mutant 4 , followed by the Putative mutant 1 and Putative mutant 2 (0.75). Putative mutant 3 and both the parents (Parent 1 and Parent 2) showed least pair-wise similarity $(0.24)$. The population average was 0.49. This proves that the Putative mutant 3 could be isolated as solid mutant for M2 generation. In RAPD analysis, (Fig. 1) the clusters were identified in such a manner that the similarity within the group was greater but between groups, it should be less. Thus, all the point of population average of 0.46 similarities, the cluster was designated and it resulted in identification of three major clusters. Cluster I included two parents (Parent 1 and Parent 2) and three putative mutants, i.e. Putative mutant 1, Putative mutant 4 and Putative mutant 2. Cluster II had two putative mutants; viz., Putative mutant 5 and Putative mutant 6. Putative mutant 3 is placed separately as different taxa. The 3D plot of first three principal components is presented in Fig. 2. PC 1, PC 2 and PC 3 used for depicting the three dimensional coordinates explained 29.94\%, $19.02 \%$ and $8.94 \%$ variation. Since it is only $57.9 \%$ variation, 60 principal components were required to explain $100 \%$ variation. Three groups were identified the PCA and among them cluster 1 was identified to be more diverse

Mutation that results in overt phenotypes reflecting the function of the corresponding gene, however, can be uncovered by mutagenesis for two main reasons. First, many genes are functionally redundant, sharing overlapping functions with other genes that may or may not be related at the sequence level (Pooler and Scorza, 1995). Secondly, many genes function at multiple stages of development. Mutations in these genes may lead to early lethality or may be highly pleiotropic, which can mask the role of a gene in a specific pathway (Hallden et al., 1996). Due to these reasons, the using the morphological characters selection of the solid mutant is very difficult from the large putative mutants population. In the RAPD assay, the nature of the fragments that are amplified is highly dependent on the primer sequence and on the genomic DNA sequence being assayed. Primers differing by a single nucleotide generate quite different profiles. Thus, this technique may detect single base changes in genomic DNA if sufficient primers are assayed (Gilmour, 1994). Among all the genotypes, the highest level of dissimilarity was observed in pm3 with the parents. Randomly amplified polymorphic DNA markers, which can quickly detect a large number of genetic polymorphism, have led to the creation of genetic maps in a number of crops (Luo et al., 2002) and RAPD markers have used to detect mutations and DNA damage (Atienzar et al., 2002),. Similarly, Yang and Schmidt (1994) used the RAPD analysis to differentiate mutants developed by X-rays treated cherry leaf plants. Concurrent report was made by Deng et al., 1995 reported that RAPD analysis can be used for lime for the identification of 14 in vivo and one in vitro lemon mutants in comparison with a known zygotic origin genotype (Fig. $3)$.

\section{Mutant identification with molecular markers}

The pm 3 was found most dissimilar (0.24) with the parents. The pm1 and pm4 was had found almost similar coefficient $(0.70$ and 0.61 respectively) to the parents and also they were quite similar with each other $(0.78)$. The pm3 can be regarded as solid mutant. pm 5, 6 are similar to each other and can be isolated as solid mutant as they are different than the parent at 0.45 similarity coefficient value. 
Here it could be concluded that the Putative mutant 3, 5 and 6 were isolated as solidd mutants in M1 generation.

\section{References}

Atienzar, F. A., Venier, P., Jha, A.N. and Depledge, M.H. 2002. Evaluation of the random amplified polymorphic DNA (RAPD) assay for the detection of DNA damage and mutations, Mutation Res./Genet. Toxicol. Environ. Mutagen., 521: 151-163.

Bandyopadhyay, P., Das, D.K. and Chattopadhyay, T.K. (1997). Correlation and path analysis in seed production of marigold as affected by the micronutrient application. Hort. J., 10: 73-78.

Deng, Z.N., Gentile, E., Nicolosi, E., Domina, F., Vardi, A. and Tribulato, E. (1995). Identification of in vitro and in vivo lemon mutants by RAPD markers. $J$. Hort. Sci., 70: 117-125.

Gilmour, M. 1994. The BCCCA Ring test on the RAPD analysis of cocoa. Proc. Int. Work Cocoa Breed. Start. Kuala Lumpur, pp.135-138.

Hallden, C. Hansen, M. Nilsson, N., Hjerdin, A. and Sall, T. 1996. Competition as a source of error in RAPD analysis. Theor. Appl. Genet., 93: 1185-1192.

Johnson, H.W., Robinson, H.F., Comstock, R.E. 1955. Estimates of genetic and environmental variability in soybean. Agron. J. 47: 477-483.

Lefort, F. and Douglas G. C. 1999. An efficient micro-method of DNA isolation from mature leaves of four hard-wood tree species. Ann. Forest Sci., 56: 259-263.

Leyser, M. 2000. Genetics and Analysis of Quantitative Traits. Sinaure Assocs. Inc., Sunderland, Massachusetts, USA, 980p.

Luo, S., He, P., Zheng, X. and Zhou, P., 2002.
Inheritance of RAPD markers in an interspecific F1 hybrid of grape between Vitis quinquangularis and $V$. vinifera. Sci. Hort., 93:19-28.

Maple, A.J. and Moller, J.P. 2007. Cytogenetics of mutants in triticale. Plant Breed Rev. 5: 41-93

Omar, C., Alikarnanoglub, S., Acik, L. and Canbolatb, Y. 2008. Plant breeding program aided by radiation treatment. Calif. Aggr., 14:4-5.

Pooler, M. and Scorza, R. 1995. Aberrant transmission of RAPD markers in haploids, double haploids and $\mathrm{F}_{1}$ hybrids of peach: Observations and speculations on causes. Sci Hort., 64: 233-241.

Raghava, S.P.S. 1995. Genetic improvement of African marigold In: Proc. National Seminar on Ornamental Horticulture and Environment, Calcutta, 111-119.

Reiter, R.S., Williams, J.G.K., Feldman, K.A., Rafalski, A., Tingey, S.V. and Scolnik, P.A. 1992. Global and local genome mapping in Arabidopsis thaliana by using recombinant inbred lines and random amplified polymorphic DNAs. Proc. Natl. Acad. Sci. USA., 89: 1477-1481.

Rohlf, F.J. (2000). NTSYS-pc Numerical taxonomy and multivariate analysis system, Version 2.02 extern software, Setauket, New York, USA, pp.843.

Sangyoung, N., Kyoungmi, K., Hanchul, K. and Kang, H. C. 2007. Selection of a primer in the randomly amplified polymorphic DNA (RAPD) analysis for genetic relationship of grapes. RDA Journal of Hort. Sci., 40: 30-35.

Tsaftaris, A.S., Kafka, M., Polidoros, A. and Tani, E. 2006. Epigenetic change in Vigna mungo DNA and mutagenesis In: J.G. Coors and S. Pandey (eds.), Genet. Exploit. Heterosis Crop, pp. 195-203.

Wang, H., Parent, S., Gosseliu, A. and 
Desjardins, Y. 1993. Vesiculararbuscular mycorrhizal peat-based substrates enhance symbiosis establishment and growth of three micropropagated species. J. American Hort. Sci., 118: 896-901.

William, J.G.K., Kubelic, A.R., Livac, K.J., Rafalski, J.A. and Tingey, S.V. 1990. DNA polymorphism amplified by arbitrary primers is useful as genetic markers. Nucleic Acid Res., 18: 65316535.

Yang, H. and Schmidth, H. 1994. Selection of mutants from adventitious shoots formed in X-rays treated cherry leaves and differentiation of standard and mutant with RAPDs. Euphytica, $77: 89-92$

\section{How to cite this article:}

Jayoti Majumder, S. K. Singh and Manjusha Verma 2018. Assessment of Mutation in Marigold (Tagetes erecta L.) using Morphological and Molecular Markers Int.J.Curr.Microbiol.App.Sci. 7(07): 2588-2597. doi: https://doi.org/10.20546/ijcmas.2018.707.303 